\title{
Population Fertility as an Evaluation of The Success of Family Planning in Jatisari Village Pakisaji District, Malang Regency
}

\section{Budijanto ${ }^{\text {a, } 1}$}

a Departement of Geography, Faculty of Social Science, Universitas Negeri Malang, Malang, Indonesia

${ }^{1}$ budijanto.fis@um.ac.id

\begin{tabular}{ll}
\hline \multicolumn{2}{l}{ Informasi artikel } \\
\hline Sejarah artikel & \\
Diterima & $: 18$ Aug 2019 \\
Revisi & $: 19$ Nov 2019 \\
Dipublikasikan & $: 1$ Dec 2019 \\
\hline
\end{tabular}

\section{Kata kunci:}

Fertilitas penduduk PUS

Evaluasi keberhasilan KB

\begin{abstract}
A B S T R A K
Penurunan fertilitas dan perbaikan kesehatan masyarakat menjadi tujuan utama untuk meningkatkan kesejahteraan keluarga. Tujuan dari penelitian ini untuk mengetahui tingkat fertilitas Dusun Kedampul Desa Petung Sewu Kecamatan Tumpang Kabupaten Malang dan untuk mengevaluasi keberhasilan program KB pada PUS tersebut. Penelitian ini merupakan penelitian survei dengan populasi pasangan usia subur di Dusun Kedampul Desa Petung Sewu Kecamatan Tumpang Kabupaten Malang. Tehnik pengambilan sampel PUS dari responden secara purposive, dan wawancara sebagai tehnik utama dalam pengumpulan data. Hasil penelitian menunjukkan bahwa angka fertilitas PUS masih tinggi pada PUS yang bukan akseptor dari pada PUS yang sebagai asseptor signifikan fertilitas pada masyarakat akseptor dengan non akseptor berdasarkan umur kawin pertama, lama periode reproduksi, pendidikan istri, pendapatan keluarga dan mortalitas bayi, dan ada perbedaan yang tidak signifikan perbedaan fertilitas berdasarkan pemakaian alat kontrasepsi. Namun secara simultan ke enam variabel bebas mempunyai hubungan yang signifikan dengan fertilitas untuk PUS akseptor dan non akseptor. Bobot sumbangan terbesar diberikan oleh variabel mortalitas bayi dan terkecil oleh pemakaian alat kontrasepsi.
\end{abstract}

\section{Keywords:}

CRA population fertility

Evaluate the success of family

\begin{abstract}
A B S T R A C T
The decrease of fertility and improving public health are the main objectives to improve family welfare. The purpose of this study was to determine the fertility level of Kedampul Hamlet in Petung Sewu Village, Tumpang District, Malang Regency and to evaluate the success of family planning (KB) program of Couples of Reproductive Age (CRA) in that area. This research is a survey research with population of couples of reproductive ages in Kedampul Hamlet. The CRA sampling technique of the respondent is purposive, and interview as the main technique in data collection. The results showed that the fertility rate of CRA is higher in non-acceptor than the acceptor. The fertility of acceptor communities with non-acceptors are based on age of first marriage, span of reproduction period, wife's education, family income and infant mortality. There is a no significant difference in fertility based on the use of contraceptive. However, simultaneously the six independent variables have a significant relationship with fertility for acceptors and nonacceptors CRA. The largest contribution is given by the infant mortality variable and the smallest by the use of contraceptive.
\end{abstract}

\section{Introduction}

One of the objectives of the family planning program that began in 1970 is to improve the welfare of the family. The family welfare appears to be the main theme for the last twenty years. Absolutely, to achieve the goal there are stages to be passed, one of them is the improvement of public health and the campaigns of fertility reduction.

(C) 2019 (Budijanto). All Right Reserved

Severe challenges and winding roads are taken to lower fertility rates and improve the level of public health. A big effort involving the whole layer of society seemed to be not in vain. The fertility rate (TFR and CBR) has decreased. TFR descended from 5.6 children per mother in the period of 1961-1971 to 4.9 children per mother in the period 1971 - 1980, became 4.2 in the period of 1980-1990 and became 3.2 in the period of 
1990-2000, but due to the monetary crisis declining the economic potential of the community has been increased again to 3.5. So did CBR down from 43.0 in 1971 - 1980 to 38 in 1980 - 1990, to 24 per thousand in the year 1990-2000 and an increase to 29 per thousand in the period of the year 2000-2010. The population growth rate decreased from $2.34 \%$ in the period 1971 - 1980 to $1.97 \%$ in the period of 1980 1990 , to $1.49 \%$ in $1990-2000$ and there was a slight increase to the $1.68 \%$ period in $2000-2010$ (BPS, 2010).

The economy structure of Malang population, in general and Pakisaji Sub-district in particular, rely on the agricultural sector with the average land ownership with less than 0.2 ha, even many farmers do not have the land at all. On the other hand, Pakisaji subdistrict is directly adjacent to Malang, so this area is a pheryperi area that become the target of urban people, who can not afford to buy residence in urban areas. As a result, it is not surprising if the economic structure besides the agricultural sector is service-related sector and the informal sector. The economic structure as mentioned before, encourages women and children to work to be able to lessen family's economic burden. In addition, the city expansion led to the more complex of pheryperi area, and continuously decreasing of agricultural land.

Moreover, due to the multi-dimensional monetary crisis in 1997/1998, it was declining community's welfare, the community's affordabilty to buy contraceptive was lessen and BKKBN bankruptcies do not able to provide contraceptive at the time. It cause "baby boom" to be happened in 2000, which is predicted by the demographic experts in 2020-2030 in Indonesia will get a demographic dividend. Demographic bonus, is condition where the population with productive age is abundant while the young age is decreasing and the elderly age is not much. The number of working age (15-64 years old) in 2020-2030 will reach 70 percent, the rest are 30 percent, is an unproductive age (under 15 years and above 65 years). This condition is also followed by the increasing of the couples of reproductive age (CRA) so that will determine the level of fertility, especially in Jatisari village which is the lowest CRA in of Pakisaji subdistrict.

To find out how far the CRA woman engages in family economic activity at home by limiting the number of children, it needs to be researched. Based on that background, this research carried out the topic on "Population fertility in Pakisaji Village, Malang regency". The results of this research are expected to be used as an evaluation of the implementation of family planning and to improve the quality of human resources in order to compete in the globalization era.

The results of preliminary survey, shows that there factor keep encouraging the high fertility is, they do not have time to take the contraceptive due to their business to work. In addition, in the environment of poor settlements have limitations of health infrastructure, low education that influence the lack of knowledge about contraceptive, which could lead to the fertility continue to increase.

On the other hand, the population inside the city increases as a result of the growing urbanization. Thus the issue of urbanization, population density and residential density became a serious problem (Syahfrizal, 1987). Furthermore, the higher rate of urbanization of urbanization lead to the higher rate of unemployment as well, due to limited job field.

Those symptoms, also occur in the poor settlements in Malang. Based on that consideration, we want to conduct a research related to the numerous quantity but lack of quality of human resources. Therefore, the topic is: The population fertility behaviour in Pakisaji district of Malang as a tool for forming a Family Planning (KB) village in Malang Regency.. this reseach was in collaboration with BKKBN East Java province.

\section{Method}

This research is designed by using Explanatory research and Research \& Development approach. The explanatory research wants to explain the symptoms posed by an object of research, namely the influence of socio-economic background, culture and demographic, the fertility behavior of the population. To determine the research location and target program, are based on: The characteristic of population fertility behavior in Pakisaji Malang. This area is the village with low acceptor and high fertility rate. Therefore, the selection of the 
reasearch location is done purposively, which defined as the determination are chosen based on certain considerations (Singarimbun, 1989). Besides of that, the village was one of left behind villages. With a low number acceptors of Couples of Reproductive Age (CRA) that would later be used as models of Family Planning (KB).

As a respondent in this study is the entire household of CRA that whether becomes or does not become an acceptor in fertile years (15-49) in Jatisari village. The sample of this research are 75 respondents. The number of respondents for each hamlet is determined by purposive sampling, which has spesific characteristic, there are the households who are whether acceptor or non-acceptor CRA of Family Planning (KB). Next, to get the respondents of each CRA sample used sistematic random sampling, which only the first element is chosen randomly, while the next element is determined by the interval $\mathrm{K}$ or selected systematically or according to a specific pattern (Supranto, 1973, Mantra and Kasto, 1985).

To gain the data in this study these techniques are used: Participatory observation by means of researchers directly involved in the implementation of program; the study of the documentation, Interviews, conducted by meeting directly with the respondents using the interview guidelines.

The data analysis in this study was conducted with both quantitative and qualitative techniques. Quantitative data analytzed by using percentages and statistics tables. While qualitative data analysis in two ways: first perform case by case analysis which done simultaneously, at this stage, a temporary conclusion has been made in all cases on each research subject, and; Secondly perform analysis between cases, at this stage, the analysis is carried out against the findings of the provisional (the result of a case by case analysis) and is expected to find a background of an acceptor or a nonacceptor of KB.

\section{Results and discussion}

Number of children born alive (Fertlity). Fertility is the number of children born alive. From the calculation result, the data is obtained as in table 1.

Table 1

Number of children born alive between acceptor and non-acceptor CRA

In Malang Regency of 2018

\begin{tabular}{lcccc}
$\begin{array}{l}\text { The number } \\
\text { of fertility }\end{array}$ & $\begin{array}{c}\text { Non Acceptor } \\
\text { Total }\end{array}$ & Acceptor & \\
\cline { 2 - 4 } & 75 & 227 & 75 & Fx \\
Average & \multicolumn{2}{c}{3,03} & 2,57 & 192 \\
\end{tabular}

Table 1 shows that the average number of children born alive, for non-acceptor CRA the number is higher than that of acceptor CRA, The score are 3.03 for non-acceptor CRA and 2.57 for the acceptor CRA. The highest frequency for non-acceptor CRA is on fertility 3 , and for the acceptor CRA is found in fertility 2. This indicates that fertility in the non-acceptor CRA is still higher than the acceptor CRA.

\section{Fertility differences based on respondents' first married age}

To obtain an overview of fertility differences based on the respondents' first married age between the acceptor CRA and the nonacceptor CRA as in table 2.

Table. 2 Average number of children born alive according to first married age between acceptor CRA and non-acceptor CRA In Malang Regency 2018

\begin{tabular}{ccccccc}
\hline $\begin{array}{c}\text { Respon } \\
\text { dent's } \\
\text { marriag } \\
\text { e age } \\
<17\end{array}$ & \multicolumn{3}{c}{$\begin{array}{c}\text { Acceptor } \\
\text { Mother }\end{array}$ Children $\sum_{\text {fertility }}$} & & \multicolumn{2}{c}{ non acceptor } \\
Mother & $\sum_{\text {Children }} \sum_{\text {Fertility }}$ \\
$17-<20$ & 6 & 21 & 3,80 & 21 & 80 & 3,80 \\
$20-<23$ & 25 & 87 & 3,48 & 33 & 116 & 3,52 \\
$23-<26$ & 30 & 72 & 2,42 & 24 & 61 & 2,54 \\
$\geq 26$ & 23 & 47 & 2,04 & 15 & 32 & 2,13 \\
& 16 & 30 & 1,87 & 7 & 14 & 2,00 \\
Total & 75 & 192 & 2,57 & 75 & 227 & 3,03 \\
\hline
\end{tabular}


From table 2 It can be explained that the average number of children born alive is based on the first age of marriage at the entire group. For non acceptor CRA is higher than the acceptor, except in the first group of married age less than 17 years. Both for an acceptor and non-acceptor CRA alike, that is by an average of 3.8 children. It can thus be concluded that there is a difference in the average number of children born alive based on the first married age between the acceptor CRA. To know the magnitude of the difference level, it has been analyzed with $T$ test. The ( $t$ test) obtained the value of $T 4.51$ on the prohability $(P)=.000$ means there is a difference in the average number of children born alive, based on the first significant mating of the acceptor CRA and non-aceptor CRA. Thus the hypothesis that said "there is a fertility distinction based on the first married age between the acceptor and non-acceptor CRA" has been tested.

On the other hand, seeing the significant correlation between the average number of children born alive with the first married age, for the acceptor CRA is obtained $r$ value of -0.2545 at $P=-005$ and for non-acceptor CRA obtained $R$ value of 0.5261 on $P=.000$. Thus it can be concluded that there is a significant negative relationship between the average number of children born alive with the first married age for both non-acceptor and acceptor CRA. It needs to get special attention to the nonacceptor CRA that more than $50 \%$ of the women's first age married is less than 23 years old, therefore the family planning program should be thoroughly cared for by the government The first of married age which has been too early will make the numerous number of children because of the longer the fertility period.

\section{Fertility differences based on span of reproductive period}

To obtain an overview of fertility differences based on the span of the reproductive period. The results are the average number of children born alive from 200 respondents, as portrayed in table 3 .

Table 3 Average number of children born alive (CBA) based on span of reproductive period In CRA acceptor and non acceptor in Malang Regency 2018

\begin{tabular}{|l|ccc|ccc|}
\hline \multirow{2}{*}{$\begin{array}{l}\text { Reproductiv } \\
\text { e Period }\end{array}$} & \multicolumn{3}{|c|}{ Acceptor } & \multicolumn{3}{|c|}{ Non acceptor } \\
\cline { 2 - 7 } (year) & \multicolumn{2}{|c|}{$\sum$ Mother } & $\sum$ Children CBA & $\sum$ Mother & $\sum$ Children CBA \\
\hline$<5$ & 8 & 8 & 1,00 & 10 & 14 & 1,40 \\
$5-<10$ & 25 & 49 & 1,96 & 19 & 41 & 2,16 \\
$10-<15$ & 33 & 86 & 2,61 & 21 & 59 & 2,81 \\
$15-<20$ & 18 & 58 & 3,22 & 19 & 65 & 3,42 \\
$\geq 20$ & 16 & 56 & 3,50 & 31 & 114 & 3,68 \\
\hline Jumlah & 75 & 192 & 2,57 & 75 & 227 & 3,03 \\
\hline
\end{tabular}

Table 3 appears that both respondents in CRA acceptor and non acceptor's average number of children born alive has the same pattern. The results are ' low ' in the old group of the reproductive period for less thann 5 years, and ' high ' in the old group for 20 years of reproductive period. This situation shows that the longer family time lead to the higher the average number of children born alive. It is happened because their reproduction period is longer than those who only have 5 -year marriage.

However, if we pay attention at all the old groups of reproductive period of $<5$ years up to 20 years, it turns out that for thoese who are non acceptor, the average number of children born alive is higher compared to the acceptor. The high average number of children born alive in the nonacceptor CRA is closely related to the first marriage age. The average first marriage age of non-acceptor CRA are when they turns 19 years old. As a result their family time is longer as they have a longer productive age, compared to acceptor CRA who have the average of first marriage age at 22 years old.

There is a difference between the population in the acceptor CRA and the nonacceptor CRA in fertility based on the span of 
the reproduction period. To find out how significant the gap of difference applies in both CRA, the statistical calculation is done using the T-Test, apparently the result of the value is -2.69 at $P=.008$. Therefore, it can be concluded that there is a significant fertility differences based on the reproductive period between the acceptor CRA and non-acceptor CRA.

The correlation between the two variables, the value of $R$ is 0.58 at $P=.000$ for the acceptor CRA. Meanwhile, it is 0.6744 at $P=.000$ on non-acceptor CRA. Thus there is a significant relationship between the average number of children born alive with the span of the reproductive period for both CRA.

\section{Number of children born alive based on contraceptive equipment}

To obtain an overview of the fertility diversity based on the span time of contraceptives use. The data have collected from 200 respondents with the results as in table 4 .

\section{Table 4}

Average number of children born alive based on the span time of contraceptives use in acceptor and non-acceptor CRA Malang regency 2018
CRA, the average number of children born alive shows inconsistent pattern. There is almost no difference in fertility for both acceptor and non-acceptor CRA, whether they use contraceptives longer or shorter use of contraceptives.

To find out how significant the difference between both CRA is done with the T-test. Based on the result of the calculation obtained $T$ value of -1.12 at $P=$. 263. Thus, there is no significant difference in the average number of children born alive between the acceptor and the non-acceptor CRA. As a result, the hypothesis of "There is a significant difference in the average number of children born alive based on the contraceptives use between acceptor and non-acceptors CRA are insignificant" is not proven. The correlation between the average number of children born alive with the contraceptives use, for the acceptor CRA, the value is $R 0.0515$ at $P=.306$ and for the non acceptor, the $R$ value is 0.2453 at $P=007$.

\section{The difference of average number children born alive based on wife education degree}

To obtain an overview of fertility differences based on the wife's degree of

\begin{tabular}{|c|c|c|c|c|c|c|c|}
\hline \multirow{2}{*}{$\begin{array}{c}\text { Contrace } \\
\text { ptive use } \\
\text { (year) }\end{array}$} & \multicolumn{3}{|c|}{ Acceptor } & \multicolumn{3}{|c|}{ non acceptor education } & Th \\
\hline & $\sum_{N}$ & 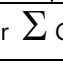 & en $C B A$ & $\sum_{M}$ & $\sum c$ & jldren CBA & ned, as stated in table 5 . \\
\hline 0 & 8 & 33 & 1,83 & 17 & 31 & 2,21 & \\
\hline$<5$ & 48 & 137 & 2,85 & 41 & 127 & 3,10 & Table 5 \\
\hline $5-<10$ & 25 & 67 & 2,68 & 31 & 109 & 3,52 & \\
\hline $10-<15$ & 5 & 13 & 2,60 & 10 & 33 & $T^{3,33}$ & \\
\hline$\geq 15$ & 4 & 7 & 1,75 & 1 & 3 & he & \\
\hline Jumlah & 75 & 192 & 2,57 & 75 & 227 & ba,63 al & ר deg \\
\hline
\end{tabular}

Based on table 4, it can be explained that women who do not use contraceptives, have smaller average number of children born alive than those who do not use contraceptives, both for acceptors and non acceptors. Most of them only have 1-2 children or even just begin marriage period. However, the average number of children born alive based on the contraceptives use in acceptor CRA is lower than on non-acceptor
In Malang Regency 2018

\begin{tabular}{|c|c|c|c|c|c|c|}
\hline \multirow{2}{*}{$\begin{array}{c}\text { Wife's } \\
\text { education } \\
\text { degree }\end{array}$} & \multicolumn{3}{|c|}{ Acceptor } & \multicolumn{3}{|c|}{ Non acceptor } \\
\hline & $\sum_{\text {Mothe }}$ & $\Sigma$ & en $C B A$ & $\sum_{\text {Mother }}$ & $\sum$ & en $C B A$ \\
\hline $\begin{array}{l}\text { Primary } \\
\text { School }\end{array}$ & 3 & 10 & 3,34 & 39 & 134 & 3,44 \\
\hline $\begin{array}{l}\text { Junior High } \\
\text { School }\end{array}$ & 30 & 96 & 3,20 & 33 & 108 & 3,28 \\
\hline $\begin{array}{l}\text { Senior High } \\
\text { School } \\
\text { Bachelor }\end{array}$ & 41 & 96 & 2,34 & 26 & 64 & 2,47 \\
\hline degree & 25 & 44 & 1,69 & 2 & 4 & 2,0 \\
\hline Total & 75 & 192 & 2,57 & 75 & 227 & 3,03 \\
\hline
\end{tabular}

Based on the table above, it can be explained that the higher education degree 
of women lead to the lower the average number of children born alive. Both for the acceptor and non-acceptor CRA so that the both CRA show the same pattern. This is because women who are educated, they have older first marriage age, as a result the reproduction period is shorter.

To find out how significant the difference value is, it has been analyzed with $T$ - test. Based on the calculation, the $T$ value obtained 6.06 at $P=.000$. It means there is a significant difference in the average number of children born alive based on wives education degree both for the acceptor and non-acceptor CRA. Then the hypothesis is proven.

The correlation value between the two variables obtained the $R$ value of 0.3818 at $P=.000$ for an acceptor CRA, and the $R$ value of -0.3623 at $P=.005$. It means that there is a significant negative correlation between the number of children born alive with the education level of wife both for acceptor CRA and non-acceptor CRA. This is because the higher women education level, the older the first marriage age, therefore the reproductive period is shorter.

\section{The difference average number of children born alive by family income}

Based on the calculation of 200 respondents, it has obtained an overview of the average number of children born alive based on family income, as mentioned in table 6 .

Table. 6

The difference average number of children born alive by family income

Malang Regency 2018

\begin{tabular}{|c|ccc|ccc|}
\hline \multirow{2}{*}{$\begin{array}{c}\text { Family's } \\
\text { Income } \\
\text { (thousands } \\
\text { Rupiah) }\end{array}$} & \multicolumn{3}{|c|}{ Acceptor } & \multicolumn{3}{|c|}{ Non acceptor } \\
\cline { 2 - 6 } & $\sum$ Mother & $\sum$ Children CBA & & $\sum$ Mother & $\sum$ Children CBA \\
\hline$<300$ & 20 & 49 & 2,45 & 33 & 104 & 3,15 \\
$300-<400$ & 23 & 55 & 2,39 & 30 & 87 & 2,90 \\
$400-<500$ & 23 & 58 & 2,52 & 20 & 67 & 3,35 \\
$500-<600$ & 10 & 25 & 2,50 & 4 & 12 & 3,00 \\
$\geq 600$ & 24 & 70 & 2,92 & 13 & 33 & 2,53 \\
\hline
\end{tabular}

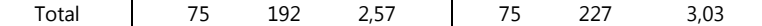

Based on the table 6 above, it can be explained that the average number of children born live almost the same for each family income group both acceptor and nonacceptor CRA. Overall the average number of children born in the non-acceptor CRA, is higher than the acceptor for the entire family income group.

To know how large the difference value to both CRA, it has been calculated with the T-Test, from the results of the analysis have obtained the value of T 3.72 at $\mathrm{P}=.000$. Meanwhile there is a difference in the average number of children born live based on significant family income between acceptor and a non-acceptor CRA. Thus the hypothesis that reads there is a difference in the average number of children born live based on family income is proven. However, the correlation between the average number of children born living with family income is as follows for the acceptor CRA obtained $R$ value of 0.0729 at $P=.235$, and for the nonacceptor CRA the value of $R$ is -0.1343 at $P$ $=$ 091. Thus there is an insignificant relationship between the average number of children born alive with the family income, both for acceptor and non- CRA acceptor.

This is due to that income is a variable that is not directly related to fertility. On the other hand the cost of childcare is quite expensive so that the high/low income will not determine the number of children owned.

\section{Number of children born alive based on infant mortality}

To obtain an overview of the diversity of fertility based on the mortality of infants from 200 respondents obtained results as in table 7.

Table. 7

The average number of children born alive based on infant mortality 
Malang Regency of 2018

\begin{tabular}{|c|ccc|ccc|}
\hline \multirow{2}{*}{$\begin{array}{c}\text { Infant } \\
\text { Mortality }\end{array}$} & \multicolumn{3}{|c|}{ Acceptor } & \multicolumn{3}{c|}{ non acceptor } \\
\cline { 2 - 7 } & \multicolumn{2}{|c|}{$\sum$ Mother } & $\sum$ Children CBA & \multicolumn{3}{c|}{$\sum$ Mother $\sum$ Children CBA } \\
\hline 0 & 67 & 137 & 2,04 & 54 & 121 & 2,20 \\
1 & 28 & 93 & 3,32 & 35 & 124 & 3,50 \\
2 & 4 & 18 & 4,50 & 11 & 58 & 5,23 \\
3 & 1 & 5 & 5,0 & - & - & - \\
\hline \multicolumn{9}{|c}{} \\
\hline
\end{tabular}

From table 7 above can be explained that the population fertility based on the mortality of infants in non-acceptor CRA is slightly higher than that of the acceptor CRA. That fact is seen from a family that has never suffered from infant mortality. To a nonacceptor CRA average number of children born alive is 2.2, meanwhile the acceptor CRA is 2.04. The situation is also found in the family whose baby mortality is 1 child that the population fertility of the non-acceptor CRA is higher than the acceptor. This insignificant difference is seen from the test result- $\mathrm{T}$ obtained the value of $\mathrm{T}-1.86$ at $\mathrm{P}=$. 064. Thus the difference in population fertility based on infant mortality is insignificant. Thus the hypothesis that reads there is a difference in fertility based on infant mortality is unproven.

But when viewed from the correlation of the population in fertility based on the mortality of the baby is very significant for both the acceptor and non-acceptor CRA. This evident is from the value of $R$ for the non-acceptor CRA, $R$ value is 0.7088 on $p=$ 000 and CRA acceptor economic $r$ is 0.6191 at $p=.000$. The higher the mortality of babies lead to the higher fertility.

This is because they are very worried when the child who is born does not reach the age of adulthood. So that those who are baby mortality is high there is a tendency to have higher fertility, too.

Based on the double regression analysis results using SPSS program acquired $F$ Value, for non-acceptor CRA is 36.89556 at $\mathrm{P}=0.000$; For the acceptor CRA is 19.596 at $\mathrm{P}=.000$. Meaning that there is a significant correlation between the population fertility with the first marriage age, long period of reproduction, long-term contraceptives use, wife education, family income and infant mortality; Both for acceptor CRA and nonacceptor CRA. Thus it can be concluded that the high and low fertility of the acceptor and non-acceptor communities can be predicted through to the six free variables.

To know the weight of effective donations (SE) in whole or from each to six free variables is as follows.

Table. 8

Effective contribution weight free variable against fertility

\begin{tabular}{|c|c|c|c|c|c|c|}
\hline \multirow{2}{*}{ Variabel } & \multicolumn{3}{|c|}{ non akseptor } & \multicolumn{3}{|c|}{ Akseptor } \\
\hline & Beta & Korelasi & SEL\% & Beta & Korelasi & SEL \% \\
\hline Umur kawin (X1) & $\begin{array}{l}-0.0888 \\
\end{array}$ & -0.5261 & 4,67 & 0.0847 & -0.2545 & 2.15 \\
\hline $\begin{array}{l}\text { Lama Per. Repro. } \\
\text { (X2) }\end{array}$ & 0.4375 & & 30,33 & 0.4869 & & 28.15 \\
\hline $\begin{array}{l}\text { Pemakaian Alat } \\
\text { Kontrasepsi (X3) }\end{array}$ & 0.2518 & 0.2639 & 6,65 & 0.886 & 0.0515 & 0.97 \\
\hline $\begin{array}{l}\text { Pendidikan Istri } \\
\text { (X4) } \\
\text { Pendapatan }\end{array}$ & -0.0673 & -0.3623 & 2,44 & -0.1551 & -0.3818 & 5.92 \\
\hline $\begin{array}{l}\text { Keluarga(X5) } \\
\text { Mortalitas Bayi }\end{array}$ & -0.0620 & -0.1343 & 0,833 & 0.0302 & 0.2545 & 0.97 \\
\hline$(\mathrm{X} 6)$ & 0.4864 & 0.7087 & 34,47 & 0.4500 & 0.6191 & 27.86 \\
\hline \multicolumn{3}{|l|}{ Total Sumbangan } & 9.39 & & 66.0 & \\
\hline
\end{tabular}

The table. 8 can be explained that the order of effective donation weights provided by the six free variables against fertility for the acceptor and non-acceptor CRA are as follows: the infant mortality rate of effective donations amounted to $34.47 \%$ of nonacceptor CRA and $27.96 \%$ for the acceptor, the duration of the reproductive period of $30.33 \%$ for non-acceptor CRA and $28.15 \%$ for the acceptor, the use of contraceptives is $6.65 \%$ for the non- acceptor CRA and wife education $5.9 \%$ for the acceptor, the first married age is $4.67 \%$ non- acceptor CRA and $2.16 \%$ for the acceptor, the education of wives is $2.44 \%$ of non-acceptors CRA, the contraceptives use and family income for acceptor CRA, respectively, $0.97 \%$ as the smallest donation weight while nonacceptor CRA. The smallest contribution for weight of donations is given by family income.

Overall of the six variables of the effective weight-free donation were given as $79.39 \%$ 
for the non-acceptor CRA and $66.03 \%$ for the acceptor. The high or low fertility is determined by first marriage age, long period of reproduction, the use of contraceptives and infant mortality. While the remaining $21.61 \%$ (non-acceptor) and $33.97 \%$ (acceptor) are determined by other variables. Thus, if you want to reduce the fertility of the population, then the six free variables should be the main consideration.

\section{Conclusion}

Starting from the discussion of research results, it can be drawn to some conclusions as follows. 1) There are differences in fertility rate of the non-acceptor and acceptor CRA, the average fertility for non-acceptor is 3.03 and acceptor CRA is 2.57. 2) There is a significant difference in fertility rate based on the first marriage age, the span of the reproductive period, wife's education and family income between the acceptor CRA and non- acceptor CRA. 3) There is no significant fertility difference based on the use of contraceptives, and the mortality of infants between acceptor and non-acceptor CRA. There is a significant correlation between the fertility with the first married age, the span of the reproductive period, the use of contraceptives, the wife education level and the mortality of infants for nonacceptor CRA. On the other hand, there is an insignificant relationship between fertility and family income. For the acceptor CRA, there is an insignificant relationship between fertility and the use of contraceptives, and family income.

In addition, infant mortality rate provides the greatest effective donation weight against fertility followed by a long reproductive period of $30.33 \%$. While the smallest effective donation weight is given by family income and wife education. For the old acceptor CRA the reproductive period provides the largest effective donation weight and followed by infant mortality.
While the smallest effective donation weight is given by family income and the use of contraceptives. Both for the acceptor and non-acceptor CRA. Partially, there are significant correlations between fertility and the six free variables. Therefore, the high or low fertility of acceptor and non-acceptor CRA can be predicted through those six free variables.

\section{References}

Arikunto, Suharsimi,1987, Prosedur Penelitian Suatu Pendekatan Praktek, Jakarta, PT. Bina Aksara.

Benyamin Lamenta. 1997. Akseptoralisasi dan Urbanisasi Sebagai Pendukung Keberhasilan KB. LDFEUI, 1997, Jakarta.

Biro CRAat Statistik, Perkiraan Angka Kelahiran Dan Kematian. Hasil Sensus 1971 dan 1980. Jakarta, 1983.

BPS, 1992. Sensus Penduduk Indonesia Tahun 1990. BPS, Jakarta.

Daldjoeni, N.,1986, Masalah Penduduk Dalam Fakta Dan Angka, Bandung, Alumni.

Entjang, Indang, 1986, Pendidikan Kependudukan dan Keluarga Berencana, Bandung, Alumni

Goldscheider, Calvin,1985, Populasi, Modernisasi, Dan Struktur Sosial, Jakarta CV. Rajawali.

Haryono Suyono, 1996 Warta Demografi Edisi Khusus 1997. LD (FEUI)

Hull, T.H, Population Control In Village Java: The Case of Maguwoharjo. Melbourn: Centre of Southeast Asian Studies.

Kuznetz, S., Fertility Differentials Between Less Developed Region: Component and Implication. Discussion Paper No. 217, Economics Growth Centre, Yale University, 1974

Labovitz, Sanford, 1982, Metode Riset Sosial, Kanada, Universitas Victoria

Lubis, Firman, 1982, Masalah Kependudukan Dan Kesehatan Masyarakat, Jakarta, Fakultas Kedokteran Universitas Indonesia.

Lucas, D., McDonald E. Young Ch. Young. Pengantar Kependudukan. CRAat Penelitian dan Studi Kependudukan Universitas Gajah Mada. Yogyakarta.

Lucas, David, et al.,1987, Pengantar Kependudukan, CRAat Penelitian dan Studi Kependudukan Universitas Gajah Mada, 
Yogyakarta, Penerbit Universitas Gajah Mada Press.

Monash University, Kertas Kerja No. 3, 1974. dan V.J. Hull, Hubungan Antara Status Ekonomi dan Fertilitas: Sebuah Analisa Data dari Indonesia (Terjemah: peter hagul). Lembaga kependudukan Universitas Gadjah Mada, Yogyakarta, 1974.

Papayungan M.M., Pergeseran Fertilitas Alamiah Ke Pembatasan Fertilitas di Sulawesi Selatan. Lembaga Penerbitan Universitas Hasanuiddin. Ujung Pandang. 1985

Partoadmodjo, S., Masalah Lingkungan dan Pembangunan Lingkungan Hidup Dunia. Training Dasar Andal Angkatan ke X PPLH Bogor, 1980.

Prawiroatmodjo Dendrasurono, 1988, Ekonomi Kependudukan dan Lingkungan: Pertumbuhan Penduduk dan Pembangunan di negaranegara Berkembang, Jakarta, P2LPTK.

Priyono Tjipto Heryanto, Warta Demografi Edisi Khusus, 1997 LDFEUI Jakarta, Republika, Februari 1997.
PBB, 1996, World Population Data Sheet., PPSK UGM Yogyakarta.

Singarimbun, M., Liku-liku Penurunan Kelahiran. LP3ES dan Lembaga Kependudukan Universitas Gadjah Mada, Yogyakarta, 1982.

Singarimbun, Masri, 1978, Faktor-faktor Sosial dan Kebudayaan Yang Mempengaruhi Fertilitas dan Mortalitas. Yogyakarta, Penerbit Lembaga Kependudukan Universitas Gajah Mada.

Singarimbun, Masri dan Sofian Effendi, 1989, Metode Penelitian Survai, Jakarta, LP3ES.

Sutrisno, Hadi, 1981, Metodologi Research, Yogyakarta, Yayasan Penerbit Fakultas Psikologi Universitas Gajah Mada.

Todaro, M.P., Pembangunan Ekonomi di Dunia Ketiga. Ghalia Indonesia, Jakarta,1983.

Vinoskis, M.M., Penurunan Fertilitas Abad ke 19 di Amerika Serikat. Penerbit Lukman Offset, Yogyakarta.

Wirosuhardjo, K., dkk., Kebijaksanaan Kependudukan dan Ketenagakerjaan di Indonesia. LPFE Universitas Indonesia, Jakarta, 1986 